\title{
Effects of ghrelin on protein expression of antioxidative enzymes and iNOS in the rat liver
}

Branislava Dobutovic ${ }^{1}$, Emina Sudar ${ }^{1}$, Snezana Tepavcevic ${ }^{2}$, Jelena Djordjevic ${ }^{2}$, Ana Djordjevic ${ }^{2}$, Marija Radojcic ${ }^{2}$, Esma R. Isenovic ${ }^{1}$

\begin{abstract}
'Laboratory for Radiobiology and Molecular Genetics, Vinca Institute of Nuclear Sciences, University of Belgrade, Belgrade, Serbia

2Laboratory for Molecular Biology and Endocrinology, Vinca Institute of Nuclear

Sciences, University of Belgrade, Belgrade, Serbia
\end{abstract}

Submitted: 11 December 2012

Accepted: 24 February 2013

Arch Med Sci 2014; 10, 4: 806-816

DOI: 10.5114/aoms.2014.44872

Copyright @ 2014 Termedia @ Banach

\author{
Corresponding author: \\ Prof. Dr Esma R. Isenovic \\ Institute Vinca \\ University of Belgrade \\ Laboratory for Radiobiology \\ and Molecular Genetics \\ P.O. Box 522 \\ 11000 Belgrade, Serbia \\ Phone/fax: +38111-3408174 \\ E-mail: isenovic@yahoo.com, \\ esma@vinca.rs
}

\begin{abstract}
Introduction: We investigated the effects of ghrelin on protein expression of the liver antioxidant enzymes superoxide dismutases (SODs), catalase (CAT), glutathione peroxidase (GPX), and glutathione reductase (GR), nuclear factor $\kappa B(N F \kappa B)$ and inducible nitric oxide synthase (iNOS). Furthermore, we aimed to investigate whether extracellular regulated protein kinase (ERK1/2) and protein kinase B (Akt) are involved in ghrelin-regulated liver antioxidant enzymes and iNOS protein expression.

Material and methods: Male Wistar rats were treated with ghrelin $(0.3 \mathrm{nmol} /$ $5 \mu \mathrm{l}$ ) injected into the lateral cerebral ventricle every $24 \mathrm{~h}$ for 5 days, and $2 \mathrm{~h}$ after the last treatment the animals were sacrificed and the liver excised. The Western blot method was used to determine expression of antioxidant enzymes, iNOS, phosphorylation of Akt, ERK1/2 and nuclear factor $\kappa B$ (NFKB) subunits 50 and 65.

Results: There was significantly higher protein expression of CuZnSOD $(p<0.001)$, MnSOD ( $p<0.001)$, CAT $(p<0.001), \mathrm{GPx},(p<0.001)$, and GR $(p<0.01)$ in the liver isolated from ghrelin-treated animals compared with control animals. In contrast, ghrelin significantly $(p<0.01)$ reduced protein expression of iNOS. In addition, phosphorylation of NFKB subunits $p 65$ and p50 was significantly ( $p<0.001$ for $p 65 ; p<0.05$ for $p 50)$ reduced by ghrelin when compared with controls. Phosphorylation of ERK1/2 and of Akt was significantly higher in ghrelin-treated than in control animals $(p<0.05$ for ERK1/2; $p<0.01$ for Akt).

Conclusions: The results show that activation of Akt and ERK1/2 is involved in ghrelin-mediated regulation of protein expression of antioxidant enzymes and iNOS in the rat liver.
\end{abstract}

Key words: Akt, ERK1/2, superoxide dismutase, catalase, oxidative stress, nuclear factor $\kappa \mathrm{B}$.

\section{Introduction}

Ghrelin, a 28 amino acid peptide, is the main endogenous ligand for the growth hormone $(\mathrm{GH})$ secretagogue receptor (GHSR) [1, 2], and is secreted primarily from the stomach, but its transcripts have also been found in the liver, suggesting its extra-endocrine as well as endocrine action [1-3]. The relationship between oxidative stress (OxS) and the expression or function of ghrelin has been reported by several research- 
ers [4-6]. In addition, ghrelin administration is expected to reduce OxS and thereafter prevent the onset of different diseases [5, 7]. Moreover, ghrelin has an anti-inflammatory action on the oxidative injury of diverse organs, such as the heart, liver and pancreas [5, 8-12].

Oxidative stress reflects an excessive bioavailability of reactive oxygen species (ROS), which is the net result of an existing imbalance between production and destruction of ROS, with the latter being affected by antioxidant defenses [13]. The removal of ROS and free radicals [14] is achieved through enzymatic and non-enzymatic reactions. Antioxidant enzymes such as superoxide dismutase (SOD), catalase (CAT), glutathione peroxidase (GPX) and glutathione reductase (GR) represent protective response against oxidative tissue damage $[1,15]$.

Inducible nitric oxide synthase (iNOS; NOS2) is a protein that produces high amounts of nitric oxide (NO), and NO is highly reactive with other free radicals. Nitric oxide reacts with superoxide $\left(\mathrm{O}_{2}^{-}\right)$ producing peroxynitrite, which in turn leads to protein nitration, DNA damage, and poly (ADP-ribose) polymerase activation [16, 17]. Therefore, the predominant role of iNOS is thought to relate to OxS-mediated host defense against tumor cells and microorganisms $[16,18]$.

Upregulation of iNOS gene transcription requires the transcriptional factor nuclear factor- $\kappa \mathrm{B}(\mathrm{NF \kappa B})$ in human and rat hepatocytes [19]. In inflamed liver, liver cells are situated in an environment where NO is generated from surrounding cells and from liver cells themselves $[19,20]$. It has been shown that redox-sensitive transcriptional factor NFKB is an important stress sensor playing a crucial role in determining cellular fate during OxS [21, 22]. Nuclear factor $\kappa \mathrm{B}$ is known to be activated by ROS and its activation leads to the transcriptional activation of numerous genes including antioxidant enzymes and iNOS [22-27].

The effects of ghrelin are mediated via a complex set of intracellular signaling pathways, including two kinases, extracellular regulated protein kinase (ERK1/2) and protein kinase B (Akt) $[20,28]$.

With the studies presented in this paper, the overall hypothesis that ghrelin is involved in antioxidative enzymes and iNOS protein expression in the liver is pursued. Furthermore, we hypothesized that ERK1/2 and Akt are involved in ghrelin-regulated antioxidant enzymes and iNOS in the rat liver. Given the complexity of the ghrelin system itself, and the limited amount of data related to the effects of ghrelin on regulation of liver antioxidant enzymes and iNOS in vivo, we investigated whether 5 days treatment with ghrelin caused changes in the liver protein expression of antioxidant enzymes and iNOS, and whether these changes in their level could be related to changes of the transcriptional regulator NFKB as well as changes of activation of ERK1/2 and Akt.

\section{Material and methods}

\section{Materials}

Pentobarbital anesthetic was obtained from United Pharmaceutical Works, Prague, Czech Republic, and ether was obtained from "Lek", Ljubljana, Slovenia. Ghrelin was obtained from Global Peptide Services, LLC Ft. Collins, CO, USA. A protease inhibitor cocktail (Complete Mini) was obtained from Roche, Mannheim, Germany. Reagents for the bicinchoninic acid (BCA) assay were purchased from Pierce (Rockford, IL, USA). Anti-actin monoclonal antibody was obtained from Sigma Aldrich Corporation (St. Louis, MO, USA) and from Abcam (Cambridge, U.K.). Anti-phospho-Akt $\mathrm{Ser}^{473}$, the anti-total Akt, the anti-phospho-ERK1/2, and the anti-total ERK1/2 antibodies were purchased from Cell Signaling (Beverly, MA, USA), while the anti-iNOS, the anti-NF- $\mathrm{B}$ p 65 and p50 antibodies and the secondary anti-rabbit antibodies conjugated to alkaline phosphatase (ALP) or to horseradish peroxidase (HRP) were purchased from Santa Cruz Biotechnology, Inc. (Santa Cruz, CA, USA) and from Amersham (Piscataway, NJ). Anti-MnSOD, anti-CuZnSOD, anti-GPx, and anti-GR antibodies were purchased from Stressgen (Now: Enzo Life Sciences, NY, USA) and an anti-catalase antibody from Calbiochem (CA, USA).

An enhanced chemiluminescence $(E C L)$ kit and HRP-linked rabbit IgG were obtained from Pierce (Rockford, IL, USA) or from Amersham Pharmacia Biotech (Buckinghamshire, UK). X-ray films were purchased from Agfa (Belgium). A commercial radioimmunoassay (RIA) kit was obtained from INEP, Zemun, Serbia, and the GLUC-PAP commercial test was obtained from Randox (Crumlin, UK).

\section{Animals}

Adult male Wistar rats (200-250 g), bred at the Institute of Biomedical Research "Galenika" in Belgrade, were used. The rats were kept in individual metabolic cages under a 12 : 12-h lightdark cycle, at $22 \pm 2^{\circ} \mathrm{C}$, and were fed with a balanced diet for laboratory rats composed of $20 \%$ protein, $8 \%$ cellulose, $13 \%$ moisture, $1 \%$ calcium, $0.90 \%$ lysine, $0.75 \%$ methionine + cysteine, $0.5 \%$ phosphorus, $0.15-0.25 \%$ sodium, vitamin mixture (A 10,000 IU/kg, D $31,600 \mathrm{IU} / \mathrm{kg}$, E $25 \mathrm{mg} / \mathrm{kg}$, B $120.02 \mathrm{mg} / \mathrm{kg}$ ), a mixture of minerals (in milligrams per kg: zinc 100, iron 100, manganese 30 , copper 20 , iodine 0.5 , selenium 0.1 ), antioxidants $100 \mathrm{mg} / \mathrm{kg}$, and digestible/metabolizable energy $11 \mathrm{MJ} / \mathrm{kg}$ (prepared by "D. D. Veterinarski zavod 
Subotica", Subotica, Serbia). Food and water were available to rats ad libitum. Body weight was measured daily.

Experimental protocols were approved by the official Vinca Institute's Ethical Committee for Experimental Animals and conformed to the recommendations given in "Guide for the Care and Use of Laboratory Animals" (1996 National Academy Press, Washington, D.C., USA).

\section{Surgical procedures}

Surgical procedures were performed under pentobarbital (45-50 mg/kg; intraperitoneally) and ether anesthesia. The rats were implanted with a headset and later used for intracerebroventricular (ICV) injections. A minimum recovery time of 5 days was permitted before the onset of experiments. The headset consisted of a silastic-sealed 20G cannula [20, 29-31], implanted into a lateral cerebral ventricle $1 \mathrm{~mm}$ posterior and $1.5 \mathrm{~mm}$ lateral to the bregma and $3 \mathrm{~mm}$ below the cortical surface. A small stainless steel anchor screw was placed at a remote site on the skull. The cannula and screw were cemented to the skull with dental acrylic.

\section{Experimental treatment}

After recovery, rats were divided into two groups (each consisting of six animals). The first group of rats, labeled as ghrelin, was treated ICV with $1 \mu \mathrm{g}$ of ghrelin dissolved in $5 \mu \mathrm{l}$ of phosphate buffered saline (PBS) every $24 \mathrm{~h}$ for 5 consecutive days $[20,30,31]$. The second group of control rats, labeled as CONTROL, was injected with $5 \mu \mathrm{l}$ of PBS. All ICV treatments were administered between 10:00 and 11:00 a.m., and animals were euthanized by decapitation under deep ether anesthesia $2 \mathrm{~h}$ after the last ICV injection. Livers were excised, weighed, and used for experiments. Blood was collected from each rat immediately after decapitation. Serum samples were stored at $-20^{\circ} \mathrm{C}$ for measuring insulin, glucose and free fatty acid (FFA).

\section{Liver lysate preparation}

After decapitation, rat livers were homogenized on ice with an Ultra-turrax homogenizer in buffer ( $\mathrm{pH}$ 7.4) containing (in $\mathrm{mM}$ ): $150 \mathrm{NaCl}, 50$ Tris, 2 EDTA, $10 \%$ glycerol, $1 \%$ Triton X-100, protease inhibitor cocktail with additional 2 mM PMSF, and $2 \mathrm{mM}$ sodium orthovanadate. Homogenates were centrifuged at $600 \times \mathrm{g}$ for $20 \mathrm{~min}$ at $4^{\circ} \mathrm{C}$, and obtained supernatants were ultra-centrifuged for $60 \mathrm{~min}$ at $100,000 \times \mathrm{g}$ [32], and used as the cytoplasmic fraction. Protein concentration was determined by the BCA method using bovine serum albumin as standard.

\section{Determination of serum insulin, glucose and free fatty acid concentrations}

Serum insulin levels were determined by the RIA method, using rat insulin standards, with assay sensitivity of $0.6 \mathrm{mIU} / \mathrm{l}$ and an intra-assay coefficient of variation of $5.24 \%$ and expressed as $\mathrm{mIU} / \mathrm{l}$ of serum. The glucose levels were measured using a GLUC-PAP kit according to the manufacturer's manual and expressed as mmol/l. For measurement of serum insulin, glucose and free fatty acid (FFA) levels animals were fasted overnight before collection of blood samples in order to avoid changes of insulin, glucose and FFA level induced by food intake. The serum FFA levels were determined using a modified version of Duncombe's colorimetric method [33] and expressed as mmol/l.

Also, fasting serum concentrations of both glucose and insulin were used to calculate the indices of insulin resistance [homeostasis model assessment (HOMA)-IR] and insulin secretion (HOMA- $\beta$ ) with the following formulae [34]: HOMA-IR = fasting insulin $(\mu \mathrm{U} / \mathrm{ml}) \times$ fasting glucose $(\mathrm{mM}) / 22.5$ and HOMA $\beta=20 \times$ fasting insulin $(\mu \mathrm{U} / \mathrm{ml}) /($ fasting glucose $(\mathrm{mM})-3.5)$.

\section{SDS-PAGE and Western blotting}

Equal amounts of protein (50 or $60 \mu \mathrm{g} /$ lane) were separated by $10 \%$ SDS polyacrylamide gels [35-37] and transferred to polyvinylidene difluoride membranes as previously described [38, 39]. The membranes were blocked with either 5\% nonfat dry milk or $5 \%$ bovine albumin and probed with antibodies against MnSOD (in a dilution of $1:$ 4000), CuZnSOD (in a dilution of $1: 10000$ ), GPx (in a dilution of $1: 1000$ ), GR (in a dilution of $1: 3000$ ), iNOS (in a dilution of $1: 2000$ ), NFKB subunits p50 (in a dilution of $1: 1000$ ) and $p 65$ (in a dilution of $1: 500$ ). After washing, membranes were incubated with the appropriate secondary ALP-conjugated anti-rabbit antibody (in a dilution of $1: 2000$ ) and used for subsequent detection with 5-bromo4-chloro-3-indoyl phosphate and nitroblue tetrazolium, or with the appropriate secondary HRPconjugated anti-rabbit antibody (in a dilution of 1 : 2000) or with ECL Rabbit IgG, HRP-linked whole antibody (in a dilution of $1: 5000$ ) or with $\mathrm{ECL}$ Mouse IgG, HRP-linked whole antibody (in a dilution of 1 : 2000) and used for subsequent detection by using an ECL kit. After analysis of pAkt (in a dilution of $1:$ 1000) and pERK1/2 (in a dilution of $1: 1000)$, membranes were stripped and reblotted with antibody detecting total Akt (in a dilution of $1: 1000$ ) or total ERK1/2 (in a dilution of 1 : 1000). In order to ensure equal protein loading, all blots were probed with mouse anti- $\beta$-actin monoclonal antibody. Densitometry of protein bands on X-ray film was performed by Image J analysis PC software. 


\section{Statistical analysis}

Values are expressed as means \pm SEM, with $n$ values representing the number of experiments. Statistical significance was evaluated with Student's $t$ test. The SPSS program for Windows (SPSS, Chicago, IL, USA) was used for statistical analyses. Value of $p<0.05$ was considered significant.

\section{Results}

\section{Body mass, plasma and serum metabolic} profile

Initial body mass was comparable in both the control and ghrelin groups. Mass gain during the 5 days of ghrelin treatment was not changed significantly. Blood glucose levels did not change in the ghrelin group compared with the control group. Plasma insulin level was significantly increased in ghrelin-treated rats $(p<0.01)$. Due to hyperinsulinemia and a slight non-significant increase in glucose level, HOMA-IR and HOMA- $\beta$ indices were significantly $(p<0.05)$ higher in the ghrelin group. Plasma FFA was significantly $(p<0.01)$ lower in the ghrelin than in the control group (Table I).

\section{Effects of ghrelin on protein expressions of CuZnSOD, MnSOD, CAT, GPx and $G R$ in rat liver}

We designed experiments to elucidate the possible antioxidant properties of ghrelin by measuring protein expression of the major antioxidant enzymes such as SOD, CAT, GPx, and GR in the rat liver following 5 days of administration of ghrelin. Protein expression of cytoplasmic CuZnSOD, MnSOD, CAT (Figure 1), GPx and GR (Figure 2) was significantly higher $(p<0.05 ; p<0.05 ; p<0.01$, $p<0.001$, respectively) in ghrelin-treated, compared with control rats. Taken together, those results indicate that ghrelin increased protein expression of antioxidative enzymes in the rat liver.

Effects of ghrelin on iNOS protein expression and protein level of $\mathrm{NF}_{\kappa} \mathrm{B}$ in the rat liver

We have previously shown that ghrelin administration caused an increase in serum NO [20]. Because ghrelin stimulates total plasma NO pro- duction [20], we next examined whether this effect of ghrelin is due to upregulation of iNOS. In contrast to regulation of $\mathrm{NO}$ plasma production [20], ghrelin significantly $(p<0.001)$ reduced iNOS protein level in the liver by $42 \%$ compared with controls (Figure 3).

The promoter of the gene for iNOS is the binding site for many transcription factors including NFKB in the 5'region of the gene for iNOS $[12,40]$. When rats were treated with ghrelin, the levels of $N F \kappa B$ subunits p65 (Figure $4 \mathrm{~A}$ ) and p50 (Figure 4 B) were significantly lower by $30 \%$ (p65, $p<$ $0.001)$ and by $24 \%$ (p50, $p<0.05$ ) compared with controls, respectively. These data suggest that NFKB plays a significant role in ghrelin-regulated antioxidant enzymes and iNOS expression in the rat liver.

\section{Liver ERK1/2 and Akt phosphorylation}

Since we have previously shown that stimulation of iNOS involves activation of Akt and ERK1/2 by phosphorylation in the heart tissue [20], we next examined the effect of ghrelin on phosphorylation state of Akt and ERK1/2 (Figure 5). Ghrelin significantly increased $(p<0.01)$ phosphorylation of Akt at $\operatorname{Ser}^{473}$ (Figure 5 B) and ERK1/2 at Tyr ${ }^{42}$ and $\operatorname{Tyr}^{44}(p<0.05)$ (Figure $\left.5 \mathrm{~A}\right)$. Thus, the regulation of liver antioxidative enzymes and iNOS protein expression by ghrelin requires activation of both ERK1/2 and Akt.

\section{Discussion}

The results of the present study demonstrate that ghrelin enhanced liver protein expression of ZnSOD, MnSOD, CAT, GPx and GR. Furthermore, ghrelin reduced liver protein expression of both iNOS and p65 and p50 subunits of NFkB. In addition, ghrelin stimulates the activity of Akt and ERK1/2 kinase.

Low doses of ICV ghrelin treatment for 5 days did not increase body mass (Table I). These results are in agreement with reports by others which show that after ghrelin treatment, there were no significant increases in body mass gain [41]. Also, these results are not in agreement with literature data reported by others [31, 42-44]. This inconsistency in the results could be explained by different experimental approaches, different ways of treating animals as well as doses of applied ghrelin. In

Table I. Body mass and biochemical characteristics of rats in control and ghrelin treated groups. Values are given as mean $\pm \mathrm{SEM} ; p<0.05$ was considered significant

\begin{tabular}{|c|c|c|c|c|c|c|c|c|}
\hline $\begin{array}{l}\text { Experimental } \\
\text { groups }\end{array}$ & $\begin{array}{c}\text { Initial body } \\
\text { weight [g] }\end{array}$ & $\begin{array}{l}\text { Final body } \\
\text { weight [g] }\end{array}$ & $\begin{array}{c}\text { Liver } \\
\text { weight [g] }\end{array}$ & $\begin{array}{l}\text { Glucose } \\
{[\mathrm{mmol} / \mathrm{l}]}\end{array}$ & $\begin{array}{l}\text { Insulin } \\
\text { [mIU/l] }\end{array}$ & HOMA-IR & НОМА- $\beta$ & $\mathrm{FFA}[\mathrm{mmol} / \mathrm{l}]$ \\
\hline Control & $234 \pm 8$ & $235 \pm 11$ & $9.49 \pm 0.72$ & $8.32 \pm 0.20$ & $96 \pm 7$ & $33 \pm 2$ & $375 \pm 16$ & $0.77 \pm 0.05$ \\
\hline Ghrelin & $215 \pm 8$ & $226 \pm 8$ & $8.85 \pm 0.47$ & $8.56 \pm 0.06$ & $193 \pm 18^{\star *}$ & $69 \pm 7^{\star}$ & $711 \pm 71^{*}$ & $0.49 \pm 0.03^{* *}$ \\
\hline
\end{tabular}



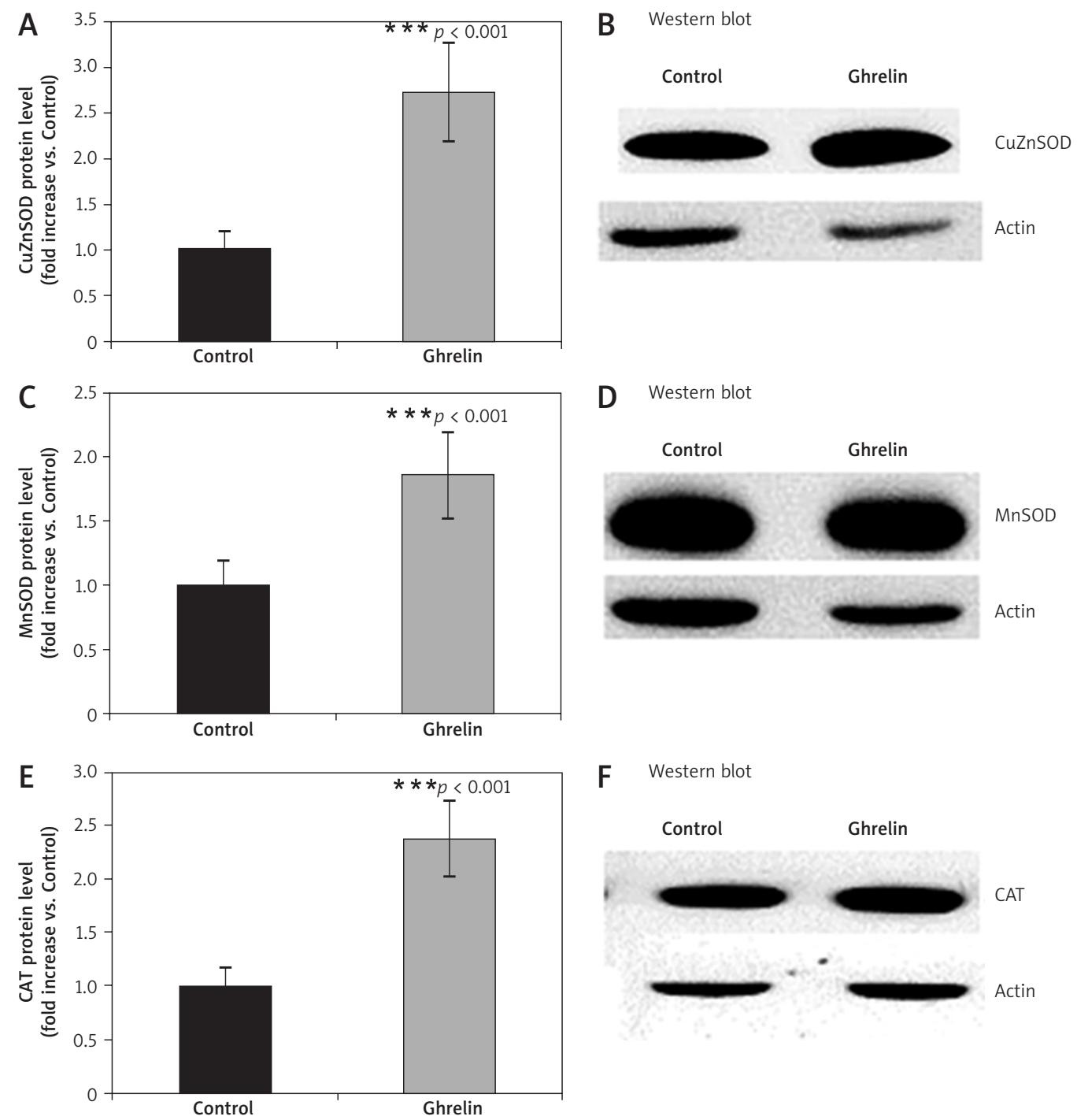

Figure 1. Effects of ghrelin on CuZnSOD ( $\mathbf{A}$ and $\mathbf{B}), \mathrm{MnSOD}(\mathbf{C}$ and $\mathbf{D})$ and CAT (E and $\mathbf{F}$ ) protein expression in the rat liver. The results are expressed as a fold increase of control (CONTROL arbitrarily set at 1 ). Results are mean \pm SEM of 4 separate experiments; $p<0.05$ was considered significant $\left({ }^{* * *} p<0.001\right)$. B, D, and $\mathrm{E}$ are representative Western blots

CUZnSOD - copper/zinc dependent superoxide dismutase, MnSOD - Mn ${ }^{2+}$ dependent superoxide dismutase, CAT - catalase

addition, it is possible that the use of different rat strains and different species of animals also contributed to the inconsistency in the results.

Treatment with ghrelin leads to an increase in serum insulin concentration, but had no effect on serum glucose concentration, which is consistent with results obtained by others [31, 44]. It is important to note that the findings in the literature of ghrelin's effect on insulin secretion are contradictory [45-47]. Lee et al. [48] reported that ghrelin treatment leads to stimulation of insulin secretion while Kamegai et al. [49] reported no significant increase in insulin concentration after ICV ghrelin treatment. It was found that intravenous administration of ghrelin inhibits insulin secretion even at increased concentrations of glucose in humans $[46,50]$. The contradiction in the results concern- ing the effects of ghrelin on insulin levels can be explained by different doses of applied ghrelin [51]. In addition, Arvat et al. [52] demonstrated that ghrelin leads to the release of $\mathrm{GH}$ in rats and humans. Injected ICV ghrelin also leads to stimulation of $\mathrm{GH}$ release in rats [41], with much lower doses of ghrelin having a more significant effect on the secretion of this hormone [53]. It is considered that the effects of ghrelin on insulin level were achieved via a central effect, i.e. its effect on the synthesis of $\mathrm{GH}$, given the low dose of ghrelin and short half-life time in circulating ghrelin $[41,54]$.

We used index values of HOMA-IR and HOMA- $\beta$ to determine whether ghrelin induces IR and affects the ability of pancreatic $\beta$ cells to secrete insulin in rats. Both indices show a significant increase in ghrelin-treated compared with control 


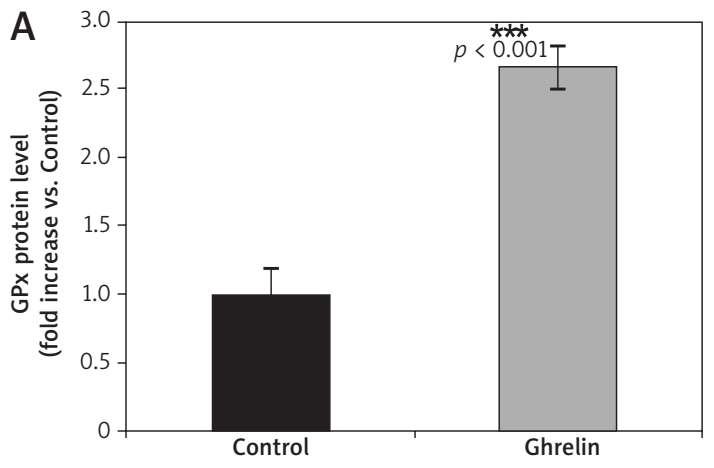

B Western blot

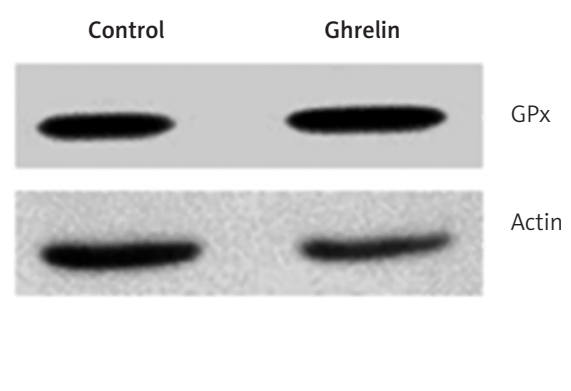

D Western blot

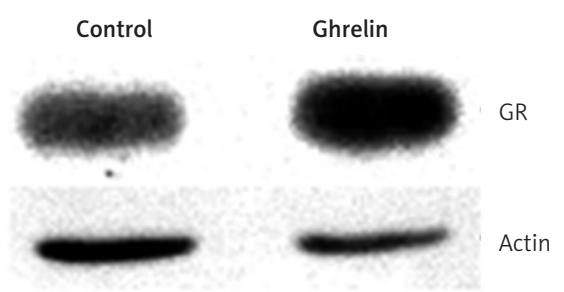

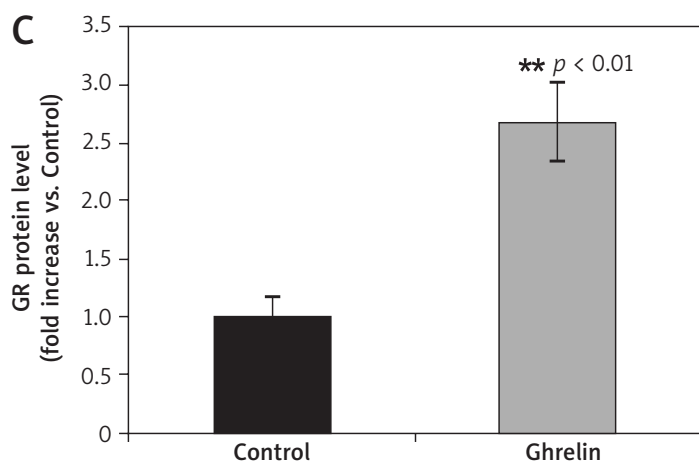

Figure 2. Effects of ghrelin on GPx ( $A$ and $\mathbf{B})$ and GR ( $C$ and $\mathbf{D})$ protein expression in the rat liver. The results are expressed as a fold increase of control (CONTROL arbitrarily set at 1). Results are mean \pm SEM of 4 separate experiments; $p<0.05$ was considered significant $\left({ }^{* *} p<0.01\right.$; $\left.{ }^{* * *} p<0.001\right)$. B and D are representative Western blots

$G P x$-glutathione peroxidase, GR - glutathione reductase

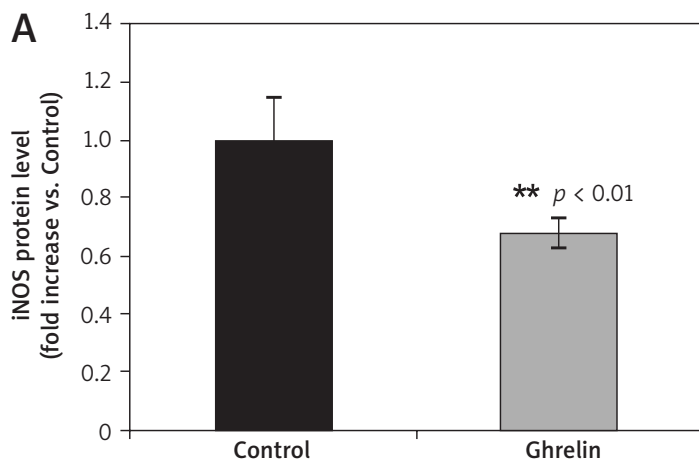

B Western blot

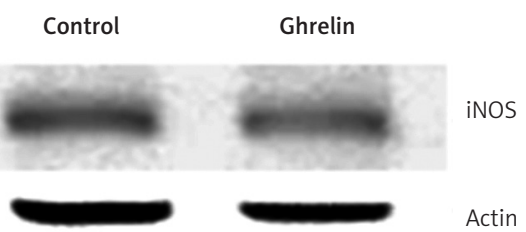

Figure 3. Effects of ghrelin on iNOS protein level in the rat liver. The results are expressed as a fold increase of control (CONTROL arbitrarily set at 1 ). Results are mean \pm SEM of 4 separate experiments; $p<0.05$ was considered significant $\left({ }^{* * *} p<0.01\right)$. B is a representative Western blot

iNOS - inducible nitric oxide synthase

rats, suggesting that there has been development of IR and insulin secretion in treated animals. In the early stages of IR, in order to achieve the physiological values of glucose, there is a compensatory increase in insulin concentrations, as our results demonstrated. However, after a period of compensated IR there is impairment in the transport of glucose, although insulin concentrations increased with increasing IR. The results of others on the effect of ghrelin on IR are controversial [55]. Poykko et al. [56] found that low levels of ghrelin in the plasma lead to the development of IR, while Vestergaard et al. [57] reported that ghrelin stimulates the development of peripheral IR.
We observed that ghrelin treatment leads to a significant decrease in FFA concentration (Table I). It is possible that the levels of FFA in the serum of animals treated with ghrelin are reduced as they are transported and stored in the cells due to increased levels of circulating insulin. The FFA and glucose are transported from the circulation into muscle cells and cardiomyocytes after meals or when cells have an increased need for them [58-60].

Our data show increased protein expression of liver ZnCuSOD, MnSOD, CAT, GPx and GR by ghrelin. The ability of ghrelin to significantly increase liver protein expression of antioxidant enzymes has 

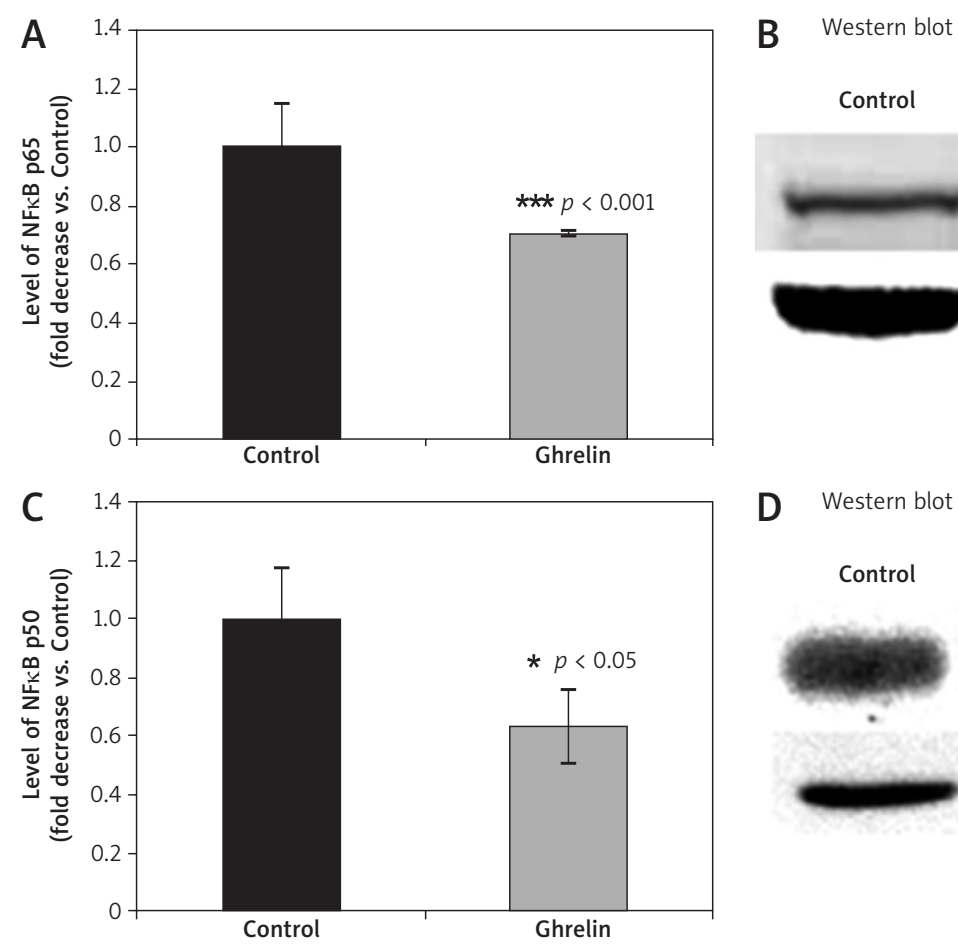

D Western blot

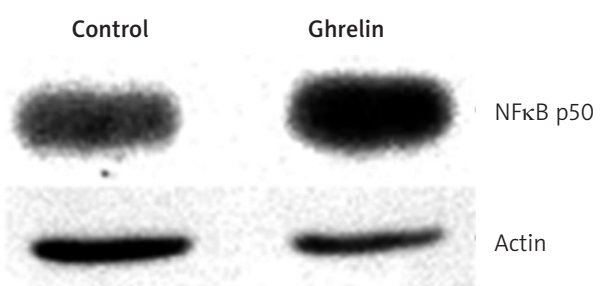

Figure 4. Effects of ghrelin on levels of p65 (A and B) and p50 NFkB (C and D) subunits in the rat liver. Results are expressed as a fold increase of control (CONTROL arbitrarily set at 1 ). Results are mean \pm SEM of 4 separate experiments; $p<0.05$ was considered significant $\left({ }^{* * *} p<0.001\right)$. B and D are representative Western blots

$N F \kappa B$ - nuclear factor $\kappa B$

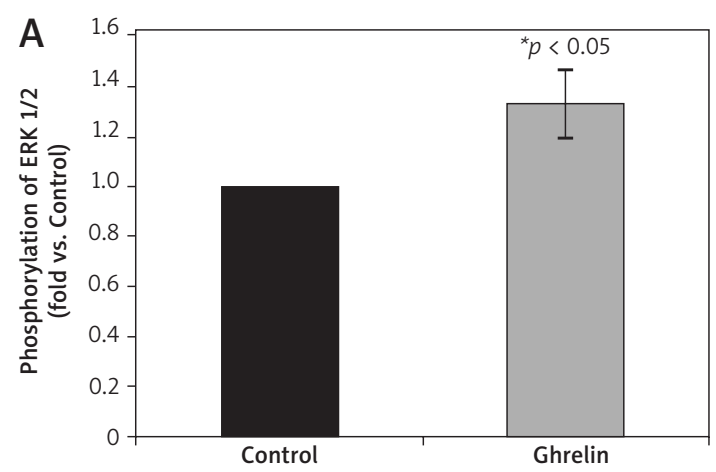

B Western blot

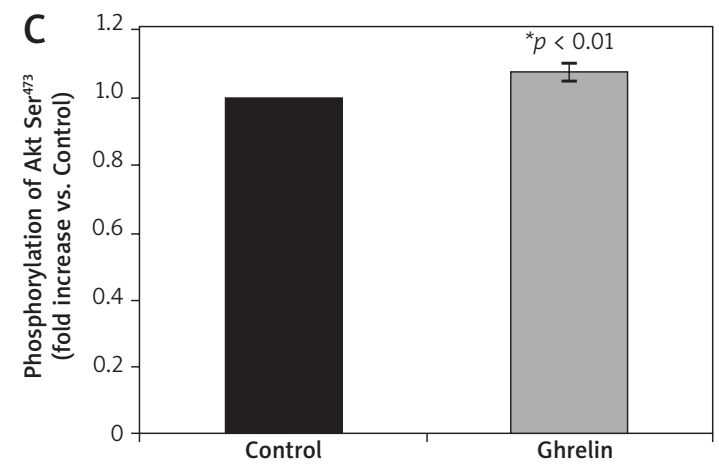

D Western blot

Control Ghrelin

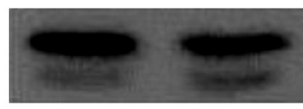

PERK $1 / 2$

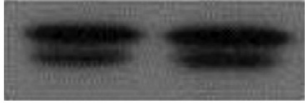

Total ERK

Control Ghrelin

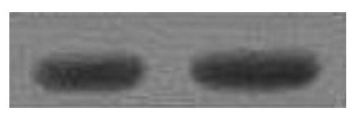

pAkt Ser ${ }^{43}$

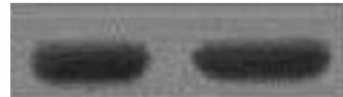

Total Akt

Figure 5. Effects of ghrelin on ERK1/2 (A and B) and Akt ( $\mathbf{C}$ and $\mathbf{D})$ phosphorylation in the rat liver. The results are expressed as a fold increase of control (CONTROL arbitrarily set at 1 ). Results are mean \pm SEM of 4 separate experiments; $p<0.05$ was considered significant $\left({ }^{*} p<0.05 ;{ }^{* *} p<0.01\right)$. B and D are representative Western blots ERK1/2 - phospho protein kinase p44/42, Akt - protein kinase B 
not been demonstrated in the rat liver in vivo, and its intracellular signal transduction pathways are not well understood. Our results confirm previous data on the antioxidative properties of ghrelin in other tissues [1, 6, 11, 61-63]. Several researchers reported the relationship between OxS and the expression or function of ghrelin [4-6]. Previous studies have reported that ghrelin has an anti-inflammatory action on the oxidative injury of diverse organs, such as the heart, liver and pancreas [5, 8-12]. In vitro studies, using human polymorphonuclear cells incubated with ghrelin, showed that ghrelin inhibited ROS generation as measured by chemiluminescence $[5,64]$. Iseri et al. [5, 65] reported that ghrelin possesses antioxidant and anti-inflammatory characteristics. Our observation of ghrelin stimulation of liver antioxidative protein expression is consistent with previous observations obtained from in vitro studies, where the authors proposed that ghrelin could protect the liver against oxidative damage [1].

Our data may indicate that ghrelin's effect on protein expression of antioxidant enzymes is dependent on some other signaling pathways, such as the insulin-like growth factor-1 (IGF-1) signaling pathway. Also, these findings raise the possibility that ghrelin has indirect effects in the regulation of liver actions through IGF-1. However, administration of ghrelin did increase plasma IGF-1 [66]. Similar to our findings in the heart [20], findings from this study support the notion that ghrelin and IGF-1 may act in parallel signaling pathways, both of which are necessary for the regulation of antioxidative enzymes, and that there is a cross-talk between ghrelin and IGF-1, where ghrelin is activated first, which further results in the activation and/ or induction of IGF-1. If induction or activation of IGF-1 receptors is needed for the action of ghrelin, this would explain why ghrelin induces protein and gene expression of antioxidative enzymes [20].

In this study, ghrelin reduced liver iNOS protein expression (Figure 3). In addition, using qRT-PCR analysis (data not shown), we measured the effects of ghrelin on the amount of Nos2 mRNA and the relative rate of transcription of the Nos2 gene. Our preliminary results indicated that changes in Nos2 mRNA level were due to changes in regulation of its transcription. Reduced Nos2 gene expression by ghrelin is in agreement with the literature data showing down-regulated expression of gastric iNOS by ghrelin [40]. These data extend our previous findings in the heart [20] that ghrelin regulates iNOS [20]. According to our knowledge there is a lack of literature data about in vivo effects of ghrelin on iNOS in rat liver.

The promoter of the gene for iNOS is the binding site for many transcription factors including NFKB in the 5 'region of the gene for iNOS $[40,67]$.
Our results show that the levels of both p50 and $\mathrm{p} 65$ subunits of $\mathrm{NFKB}$ were decreased in rat liver cytoplasm after treatment with ghrelin. Thus, it is possible that ghrelin in vivo suppresses $I_{\kappa} B-\alpha$ phosphorylation and degradation, inhibits $N F \kappa B$ nuclear translocation, and prevents iNOS gene induction [68]. These results suggest that NFKB may represent an important regulatory factor in ghrelin-induced expression of iNOS in the rat liver.

Studies in different cell types provide evidence that NFKB activation is modulated by oxidative stress $[69,70]$. Conversely, increased levels of ROS are associated with activation of NFKB [70-72]. In addition, it has been shown that increasing the ROS-inactivation capacity inside the $\beta$ cell could interrupt the cytokine-induced activation of $\mathrm{NF} \kappa \mathrm{B}$ and reduce the subsequent activation of the iNOS promoter [70].

The signaling pathway of the ERK1/2 cascade of molecules triggers phosphorylation of one another, ultimately resulting in activation of $N F \kappa B$ and regulation of gene transcription. When activated by phosphorylation, ERK1/2 can phosphorylate many target proteins, including transcription factors and protein kinases [73]. The role of ERK1/2 in the induction of iNOS has been demonstrated in several systems $[67,74-76]$. Induction of iNOS is mediated through the stimulation of ERK $1 / 2$ by NFKB $[67,76]$. In addition, it has been shown that ghrelin can activate the signaling pathway IRS-1/ MAPK [77]. The role of the ERK1/2 signaling network in ghrelin-induced activation of NFKB and iNOS expression was demonstrated by measuring the level of phosphorylation of ERK1/2. The results indicate that ghrelin leads to increased phosphorylation of ERK1/2 in the liver (Figure $5 \mathrm{~A}$ ).

On the other hand, literature data clearly indicate the important role of Akt in the regulation of NFKB and iNOS activation [68]. The results of our study show that ghrelin can activate Akt in the liver (Figure 5 B). These results support the fact that activation of Akt mediates the effects on iNOS and NFKB. These results are in agreement with the results reported by others [68], showing that the effects of ghrelin on LPS-induced up-regulation of IKK- $\beta$ and iNOS in gastric mucosa involves Akt activation [68]. Signaling through the Src/Akt pathway is known to occupy a central stage in the receptor (GHS-R)-mediated responses to ghrelin stimulation [68, 78, 79], and the recent reports suggest that the activity of IKK complex may also be subject to inhibition through S-nitrosylation of a specific cysteine residue within the activation loop of IKK- $\beta$ by the endogenous NO donors [68, 80-82].

The data presented in this paper indicate that regulation of the rat liver oxidative stress enzymes and iNOS by ghrelin involves the Akt/ 
ERK1/2 pathways because both Akt and ERK1/2 phosphorylation were increased by ghrelin administration.

The limitations of this experimental work are that no pathological insult was given to the animals to increase the reactive oxygen species in liver and then prove that ghrelin is indeed a protective and anti-oxidant peptide under pathophysiological conditions. We plan to investigate the effects of ICV administered ghrelin on antioxidative enzymes as well as iNOS in liver from high fat fed rats, a model of obesity associated with insulin resistance. This will allow us to investigate the beneficial effects of ghrelin on antioxidative enzymes as well as iNOS in pathophysiological conditions, such as obesity associated with insulin resistance. We believe that the positive effects of ghrelin in the high fat model rats will provide a reasonable rationale to further investigate the molecular mechanisms involved in ghrelin's effects on oxidative stress in pathophysiological conditions.

In conclusion, administration of ghrelin could promote an antioxidative defense system in the rat liver by increasing expression of antioxidative enzymes and reducing iNOS and NFKB protein levels through activation of Akt and ERK1/2 kinases. This finding extends previous reports concerning the antioxidative properties of ghrelin in other tissues $[1,5,6,63,65,68,83-86]$.

\section{Acknowledgments}

This work was supported by grants No. 173033 , No. III41025 and No. III41029 funded by the Ministry of Science, Republic of Serbia. We would like to thank Prof. V. Starcevic for her expertise in neuroendocrine ghrelin actions. We thank Drs. D. Stevanovic, D. Nesic and M. Djelic for their excellent contribution to in vivo experimental design, and we would like also to stress that we are grateful to them for their performance of stereotaxically intracerebroventricular implantation of cannulas, ICV ghrelin treatment for 5 days as well as for their great help with animal sacrifices, collecting blood samples, organs' excision and weighing.

\section{References}

1. Cetin E, Kanbur M, Cetin N, Eraslan G, Atasever A. Hepatoprotective effect of ghrelin on carbon tetrachloride-induced acute liver injury in rats. Regul Pept 2011; 171: $1-5$.

2. Kojima M, Hosoda H, Date $Y$, Nakazato M, Matsuo $H$, Kangawa K. Ghrelin is a growth-hormone-releasing acy lated peptide from stomach. Nature 1999; 402: 656-60.

3. Gnanapavan S, Kola B, Bustin SA, et al. The tissue distribution of the mRNA of ghrelin and subtypes of its receptor, GHS-R, in humans. J Clin Endocrinol Metab 2002; 87: 2988.

4. Suematsu M, Katsuki A, Sumida Y, et al. Decreased circulating levels of active ghrelin are associated with increased oxidative stress in obese subjects. Eur J Endocrinol 2005; 153: 403-7.

5. Suzuki H, Matsuzaki J, Hibi T. Ghrelin and oxidative stress in gastrointestinal tract. J Clin Biochem Nutr 2011; 48: 122-5.

6. Zwirska-Korczala K, Adamczyk-Sowa M, Sowa P, et al. Role of leptin, ghrelin, angiotensin II and orexins in 3T3 L1 preadipocyte cells proliferation and oxidative metabolism. J Physiol Pharmacol 2007; 58: 53-64.

7. Kyoraku I, Shiomi K, Kangawa K, Nakazato M. Ghrelin reverses experimental diabetic neuropathy in mice. Biochem Biophys Res Commun 2009; 389: 405-8.

8. Dembinski A, Warzecha Z, Ceranowicz P, et al. Role of growth hormone and insulin-like growth factor-1 in the protective effect of ghrelin in ischemia/reperfusion-induced acute pancreatitis. Growth Horm IGF Res 2006; 16: 348-56.

9. Huang CX, Yuan MJ, Huang $\mathrm{H}$, et al. Ghrelin inhibits post-infarct myocardial remodeling and improves cardiac function through anti-inflammation effect. Peptides 2009; 30: 2286-91.

10. Hedayati N, Annambhotla S, Jiang J, et al. Growth hormone-releasing peptide ghrelin inhibits homocysteine-induced endothelial dysfunction in porcine coronary arteries and human endothelial cells. J Vasc Surg 2009; 49: 199-207.

11. Xu Z, Lin S, Wu W, et al. Ghrelin prevents doxorubicininduced cardiotoxicity through TNF-alpha/NF-kappaB pathways and mitochondrial protective mechanisms. Toxicology 2008; 247: 133-8.

12. Hou Y, An J, Hu XR, et al. Ghrelin inhibits interleukin-8 production induced by hydrogen peroxide in A549 cells via NF-kappaB pathway. Int Immunopharmacol 2009; 9: 120-6.

13. Bitar MS, Ayed AK, Abdel-Halim SM, Isenovic ER, Al-Mulla F. Inflammation and apoptosis in aortic tissues of aged type II diabetes: amelioration with alpha-lipoic acid through phosphatidylinositol 3-kinase/Akt-dependent mechanism. Life Sci 2010; 86: 844-53.

14. Yilmaz N. Relationship between paraoxonase and homocysteine: crossroads of oxidative diseases. Arch Med Sci 2012; 8: 138-53.

15. Halliwell B, Gutteridge JM. Role of free radicals and catalytic metal ions in human disease: an overview. Methods Enzymol 1990; 186: 1-85.

16. Ponnuswamy P, Ostermeier E, Schrottle A, et al. Oxidative stress and compartment of gene expression determine proatherosclerotic effects of inducible nitric oxide synthase. Am J Pathol 2009; 174: 2400-10.

17. Beckman JS, Beckman TW, Chen J, Marshall PA, Freeman BA. Apparent hydroxyl radical production by peroxynitrite: implications for endothelial injury from nitric oxide and superoxide. Proc Natl Acad Sci U S A 1990; 87: 1620-4.

18. MacMicking J, Xie QW, Nathan C. Nitric oxide and macrophage function. Annu Rev Immunol 1997; 15: 323-50.

19. Li J, Billiar TR. Nitric oxide. IV. Determinants of nitric oxide protection and toxicity in liver. Am J Physiol 1999; 276: G1069-073.

20. Sudar E, Dobutovic B, Soskic S, et al. Regulation of inducible nitric oxide synthase activity/expression in rat hearts from ghrelin-treated rats. J Physiol Biochem 2011; 67: 195-204.

21. Martindale J, Holbrook NJ. Cellular response to oxidative stress: signaling for suicide and survival. J Cell Physiol 2002; 192: 1-15.

22. Djordjevic J, Djordjevic A, Adzic M, Niciforovic A, Radojcic MB. Chronic stress differentially affects antioxidant 
enzymes and modifies the acute stress response in liver of Wistar rats. Physiol Res 2010; 59: 729-36.

23. Wan XS, Devalaraja MN, St Clair DK. Molecular structure and organization of the human manganese superoxide dismutase gene. DNA Cell Biol 1994; 13: 1127-36.

24. Rojo Al, Salinas M, Martin D, Perona R, Cuadrado A. Regulation of $\mathrm{Cu} / \mathrm{Zn}$-superoxide dismutase expression via the phosphatidylinositol 3 kinase/Akt pathway and nuclear factor-kappaB. J Neurosci 2004; 24: 7324-34.

25. Zhou LZ, Johnson AP, Rando TA. NF kappa B and AP-1 mediate transcriptional responses to oxidative stress in skeletal muscle cells. Free Radic Biol Med 2001; 31: 1405-16.

26. Xu Y, Kiningham KK, Devalaraja MN, et al. An intronic NF-kappaB element is essential for induction of the human manganese superoxide dismutase gene by tumor necrosis factor-alpha and interleukin-1beta. DNA Cell Biol 1999; 18: 709-22.

27. Kim HT, Kim YH, Nam JW, Lee HJ, Rho HM, Jung G. Study of 5'-flanking region of human $\mathrm{Cu} / \mathrm{Zn}$ superoxide dismutase. Biochem Biophys Res Commun 1994; 201 1526-33.

28. Iantorno M, Chen $\mathrm{H}$, Kim JA, et al. Ghrelin has nove vascular actions that mimic PI 3-kinase-dependent actions of insulin to stimulate production of NO from endothelial cells. Am J Physiol Endocrinol Metab 2007; 292: E756-64.

29. Starcevic VP, Morrow BA, Farner LA, Keil LC, Severs WB. Long-term recording of cerebrospinal fluid pressure in freely behaving rats. Brain Res 1988; 462: 112-7.

30. Stevanovic D, Starcevic V, Vilimanovich U, et al. Immunomodulatory actions of central ghrelin in diet-induced energy imbalance. Brain Behav Immun 2012; 26: 150-8.

31. Stevanovic D, Nesic D, Milosevic V, Starcevic V, Severs WB. Consummatory behavior and metabolic indicators after central ghrelin injections in rats. Regul Pept 2008; 147: 52-9.

32. Isenovic ER, Zakula Z, Koricanac G, Ribarac-Stepic N. Insulin modulates rat liver glucocorticoid receptor. Acta Biol Hung 2006; 57: 37-48.

33. Duncombe WG. The Colorimetric micro-determination of non-esterified fatty acids in plasma. Clin Chim Acta 1964; 9: 122-5.

34. Matthews DR, Hosker JP, Rudenski AS, Naylor BA, Treacher DF, Turner RC. Homeostasis model assessment insulin resistance and beta-cell function from fasting plasma glucose and insulin concentrations in man. Diabetologia 1985; 28: 412-9.

35. Sudar E, Dobutovic B, Milosavljevic T, Putnikovic B, Gluvic Z, Isenovic ER. Interactive effects of insulin and beta-estradiol on protein kinase $b$ phosphorylation in adult rat cardiomyocytes. Acta Chimica Slovenica 2009; 56: 723-8.

36. Isenovic E, Muniyappa R, Milivojevic N, Rao Y, Sowers JR. Role of PI3-kinase in isoproterenol and IGF-1 induced ecNOS activity. Biochem Biophys Res Commun 2001; 285: 954-8.

37. Isenovic E, LaPointe MC. Role of $\mathrm{Ca}(2+)$-independent phospholipase $\mathrm{A}(2)$ in the regulation of inducible nitric oxide synthase in cardiac myocytes. Hypertension 2000; 35: 249-54

38. Isenovic ER, Fretaud M, Koricanac G, et al. Insulin regulation of proliferation involves activation of AKT and ERK $1 / 2$ signaling pathways in vascular smooth muscle cells. Exp Clin Endocrinol Diabetes 2009; 117: 214-9.

39. Livak KJ, Schmittgen TD. Analysis of relative gene expression data using real-time quantitative PCR and the 2(-Delta Delta C(T)) Method. Methods 2001; 25: 402-8.
40. Nathan C, Xie QW. Nitric oxide synthases: roles, tolls, and controls. Cell 1994; 78: 915-8.

41. Stevanovic D, Milosevic V, Nesic D, Ajdzanovic V, Starcevic $V$, Severs WB. Central effects of ghrelin on serum growth hormone and morphology of pituitary somatotropes in rats. Exp Biol Med (Maywood) 2006; 231: 1610-5.

42. Nakazato M, Murakami N, Date Y, et al. A role for ghrelin in the central regulation of feeding. Nature 2001; 409: 194-8.

43. Asakawa A, Inui A, Kaga T, et al. Ghrelin is an appetite-stimulatory signal from stomach with structural resemblance to motilin. Gastroenterology 2001; 120: 337-45.

44. Nesic DM, Stevanovic DM, Ille T, Petricevic S, Masirevic-Draskovic G, Starcevic VP. Centrally applied ghrelin affects feeding dynamics in male rats. J Physiol Pharmacol 2008; 59: 489-500.

45. Adeghate E, Ponery AS. Ghrelin stimulates insulin secretion from the pancreas of normal and diabetic rats. J Neuroendocrinol 2002; 14: 555-60.

46. Broglio F, Arvat E, Benso A, et al. Ghrelin, a natural GH secretagogue produced by the stomach, induces hyperglycemia and reduces insulin secretion in humans. J Clin Endocrinol Metab 2001; 86: 5083-6.

47. Date Y, Nakazato M, Hashiguchi S, et al. Ghrelin is present in pancreatic alpha-cells of humans and rats and stimulates insulin secretion. Diabetes 2002; 51: 124-9.

48. Lee HM, Wang G, Englander EW, Kojima M, Greeley GH Jr. Ghrelin, a new gastrointestinal endocrine peptide that stimulates insulin secretion: enteric distribution, ontogeny, influence of endocrine, and dietary manipulations. Endocrinology 2002; 143: 185-90.

49. Kamegai J, Tamura H, Shimizu T, Ishii S, Sugihara H, Wakabayashi I. Chronic central infusion of ghrelin increases hypothalamic neuropeptide $\mathrm{Y}$ and Agouti-related protein mRNA levels and body weight in rats. Diabetes 2001; 50: 2438-43.

50. Tassone F, Broglio F, Destefanis S, et al. Neuroendocrine and metabolic effects of acute ghrelin administration in human obesity. J Clin Endocrinol Metab 2003; 88: 5478-83.

51. Meyer C. Final answer: ghrelin can suppress insulin secretion in humans, but is it clinically relevant? Diabetes 2010; 59: 2726-8.

52. Arvat E, Di Vito L, Broglio F, et al. Preliminary evidence that ghrelin, the natural GH secretagogue (GHS)-receptor ligand, strongly stimulates $\mathrm{GH}$ secretion in humans. J Endocrinol Invest 2000; 23: 493-5.

53. Date $Y$, Murakami N, Kojima M, et al. Central effects of a novel acylated peptide, ghrelin, on growth hormone release in rats. Biochem Biophys Res Commun 2000; 275: 477-80.

54. Tolle V, Bassant MH, Zizzari P, et al. Ultradian rhythmicity of ghrelin secretion in relation with $\mathrm{GH}$, feeding behavior, and sleep-wake patterns in rats. Endocrinology 2002; 143: 1353-61.

55. Stepien M, Rosniak-Bak K, Paradowski M, et al. Waist circumference, ghrelin and selected adipose tissue-derived adipokines as predictors of insulin resistance in obese patients: preliminary results. Med Sci Monit 2011; 17: R13-8.

56. Poykko SM, Kellokoski E, Horkko S, Kauma H, Kesaniemi YA, Ukkola O. Low plasma ghrelin is associated with insulin resistance, hypertension, and the prevalence of type 2 diabetes. Diabetes 2003; 52: 2546-53.

57. Vestergaard ET, Gormsen LC, Jessen N, et al. Ghrelin infusion in humans induces acute insulin resistance and 
lipolysis independent of growth hormone signaling. Diabetes 2008; 57: 3205-10.

58. Jain SS, Chabowski A, Snook LA, et al. Additive effects of insulin and muscle contraction on fatty acid transport and fatty acid transporters, FAT/CD36, FABPpm, FATP1, 4 and 6. FEBS Lett 2009; 583: 2294-300.

59. Bickerton AS, Roberts R, Fielding BA, et al. Preferential uptake of dietary fatty acids in adipose tissue and muscle in the postprandial period. Diabetes 2007; 56: 168-76.

60. Kiens B. Skeletal muscle lipid metabolism in exercise and insulin resistance. Physiol Rev 2006; 86: 205-43.

61. Liu L, Xu H, Jiang H, Wang J, Song N, Xie J. Ghrelin prevents 1-methyl-4-phenylpyridinium ion-induced cytotoxicity through antioxidation and NF-kappaB modulation in MES23.5 cells. Exp Neurol 2010; 222: 25-9.

62. Iseri SO, Sener G, Saglam B, Ercan F, Gedik N, Yegen BC. Ghrelin alleviates biliary obstruction-induced chronic hepatic injury in rats. Regul Pept 2008; 146: 73-9.

63. Obay BD, Tasdemir E, Tumer C, Bilgin HM, Atmaca M Dose dependent effects of ghrelin on pentylenetetrazole-induced oxidative stress in a rat seizure model. Peptides 2008; 29: 448-55.

64. El Eter E, Al Tuwaijiri A, Hagar H, Arafa M. In vivo and in vitro antioxidant activity of ghrelin: attenuation of gastric ischemic injury in the rat. J Gastroenterol Hepatol 2007; 22: 1791-9.

65. Iseri SO, Sener G, Yuksel M, et al. Ghrelin against alendronate-induced gastric damage in rats. J Endocrinol 2005; 187: 399-406.

66. Dembinski A, Warzecha Z, Ceranowicz P, et al. Variable effect of ghrelin administration on pancreatic development in young rats. Role of insulin-like growth factor-1. J Physiol Pharmacol 2005; 56: 555-70.

67. Hou CH, Lin J, Huang SC, Hou SM, Tang CH. Ultrasound stimulates NF-kappaB activation and iNOS expression via the Ras/Raf/MEK/ERK signaling pathway in cultured preosteoblasts. J Cell Physiol 2009; 220: 196-203.

68. Slomiany B, Slomiany A. Ghrelin suppression of Helicobacter pylori-induced gastric mucosal expression of iNOS is mediated through the inhibition of IKK-beta activation by cNOS-dependent S-nitrosylation. Open Journal of Cell Biology 2011; 1: 1-10.

69. van den Berg R, Haenen GR, van den Berg H, Bast A Transcription factor NF-kappaB as a potential biomarker for oxidative stress. Br J Nutr 2001; 86 Suppl 1: S121-7.

70. Azevedo-Martins AK, Lortz S, Lenzen S, Curi R, Eizirik DL, Tiedge M. Improvement of the mitochondrial antioxidant defense status prevents cytokine-induced nuclear factor-kappaB activation in insulin-producing cells. Diabetes 2003; 52: 93-101.

71. Bonizzi G, Piette J, Merville MP, Bours V. Cell type-specific role for reactive oxygen species in nuclear factor-kappaB activation by interleukin-1. Biochem Pharmacol 2000; 59: 7-11.

72. Schmidt KN, Amstad P, Cerutti P, Baeuerle PA. The roles of hydrogen peroxide and superoxide as messengers in the activation of transcription factor NF-kappaB. Chem Biol 1995; 2: 13-22.

73. Whitmarsh AJ, Davis RJ. Structural organization of MAP-kinase signaling modules by scaffold proteins in yeast and mammals. Trends Biochem Sci 1998; 23: 481-5.

74. Xiao Z, Wang T, Qin H, Huang C, Feng Y, Xia Y. Endoplasmic reticulum $\mathrm{Ca} 2+$ release modulates endothelial nitric-oxide synthase via extracellular signal-regulated kinase (ERK) 1/2-mediated serine 635 phosphorylation. J Biol Chem 2011; 286: 20100-8.
75. Ellerhorst JA, Ekmekcioglu S, Johnson MK, Cooke CP, Johnson MM, Grimm EA. Regulation of iNOS by the p44/42 mitogen-activated protein kinase pathway in human melanoma. Oncogene 2006; 25: 3956-62.

76. Kim JW, Kim C. Inhibition of LPS-induced NO production by taurine chloramine in macrophages is mediated though Ras-ERK-NF-kappaB. Biochem Pharmacol 2005; 70: $1352-60$.

77. Murata M, Okimura Y, lida K, et al. Ghrelin modulates the downstream molecules of insulin signaling in hepatoma cells. J Biol Chem 2002; 277: 5667-74.

78. Lodeiro M, Theodoropoulou M, Pardo M, Casanueva FF, Camiña JP. c-Src Regulates Akt signaling in response to ghrelin via beta-arrestin signaling-independent and -dependent mechanisms. PLoS One 2009; 4: e4686.

79. Slomiany BL, Slomiany A. Role of ghrelin-induced cSrc activation in modulation of gastric mucosal inflammatory responses to Helicobacter pylori. Inflammopharmacology 2011; 19: 197-204.

80. Marshall HE, Hess DT, Stamler JS. S-nitrosylation: physiological regulation of NF-kappaB. Proc Nat Acad Sci USA 2004; 101: 8841-2.

81. Perkins ND. Integrating cell-signalling pathways with NF-[kappa]B and IKK function. Nat Rev Mol Cell Biol 2007; 8: 49-62.

82. Reynaert NL, Ckless K, Korn SH, et al. Nitric oxide represses inhibitory B kinase through S-nitrosylation. Proc Nat Acad Sci USA 2004; 101: 8945-50.

83. Kheradmand A, Alirezaei M, Asadian P, Rafiei Alavi E, Joorabi S. Antioxidant enzyme activity and MDA level in the rat testis following chronic administration of ghrelin. Andrologia 2009; 41: 335-40.

84. Brown-Borg HM, Rakoczy SG, Romanick MA, Kennedy MA. Effects of growth hormone and insulin-like growth factor-1 on hepatocyte antioxidative enzymes. Exp Biol Med (Maywood) 2002; 227: 94-104.

85. Barazzoni R, Zanetti M, Cattin MR, et al. Ghrelin enhances in vivo skeletal muscle but not liver AKT signaling in rats. Obesity (Silver Spring) 2007; 15: 2614-23.

86. Stępień M, Wlazeł RN, Paradowski M, et al. Serum concentration of adiponectin, leptin, resistin, ghrelin and insulin and their association with obesity indices in obese normo- and hypertensive patients - pilot study. Arch Med Sci 2012; 8: 431-6. 